\title{
Thyroid nodule update on diagnosis and management
}

\author{
Shrikant Tamhane ${ }^{1,2^{*}}$ (D) and Hossein Gharib ${ }^{1,2}$
}

\begin{abstract}
Thyroid nodules are common. The clinical importance of thyroid nodules is related to excluding malignancy ( 4.0 to $6.5 \%$ of all thyroid nodules), evaluate their functional status and assess for the presence of pressure symptoms. Incidental thyroid nodules are being diagnosed with increasing frequency in the recent years with the use of newer and highly sensitive imaging techniques. The high prevalence of thyroid nodules necessitates that the clinicians use evidence-based approaches for their assessment and management. New molecular tests have been developed to help with evaluation of malignancy in thyroid nodules. This review addresses advances in thyroid nodule evaluation, and their management considering the current guidelines and supporting evidence.
\end{abstract}

Keywords: Thyroid, Thyroid nodules, Molecular markers, Benign, Malignant, FNA, Management, Ultrasonography

\section{Background}

Thyroid nodule is a discrete lesion in the thyroid gland that is radiologically distinct from the surrounding thyroid parenchyma [1]. Thyroid nodules are common; their prevalence in the general population is high, the percentages vary depending on the mode of discovery: 2-6 \% (palpation), 19-35\% (ultrasound) and 8-65\% (autopsy data) [2-4]. They are discovered either clinically on self-palpation by a patient, or during a physical examination by the clinician or incidentally during a radiologic procedure such as ultrasonography (US) imaging, computed tomography $(\mathrm{CT})$ or magnetic resonance imaging (MRI) of the neck, or fluorodeoxyglucose (FDG) positron emission tomography; with the increased use of sensitive imaging techniques, thyroid nodules are being diagnosed incidentally with increasing frequency in the recent years $[5,6]$. Though thyroid nodules are common, their clinical significance is mainly related to excluding malignancy (4.0 to $6.5 \%$ of all thyroid nodules) [3, 7-9], evaluating their functional status and if they cause pressure symptoms.

\footnotetext{
* Correspondence: Tamhane.Shrikant@Mayo.edu

${ }^{1}$ Mayo Clinic College of Medicine, Rochester, MN 55905, USA

${ }^{2}$ Division of Endocrinology, Diabetes, Metabolism, and Nutrition, Mayo Clinic, 200 First Street SW, Rochester, MN 55905, USA
}

\section{Diagnosis and evaluation of thyroid nodules}

Thyroid nodules can be caused by many disorders: benign (colloid nodule, Hashimoto's thyroiditis, simple or hemorrhagic cyst, follicular adenoma and subacute thyroiditis) and malignant (Papillary Cancer, Follicular Cancer, Hurthle Cell (oncocytic) Cancer, Anaplastic Cancer, Medullary Cancer, Thyroid Lymphoma and metastases -3 most common primaries are renal, lung \& head-neck) $[3,10,11]$.

Initial assessment of a patient found to have a thyroid nodule either clinically or incidentally should include a detailed and relevant history plus physical examination. Laboratory tests should begin with measurement of serum thyroid-stimulating hormone (TSH). Thyroid scintigraphy/radionuclide thyroid scan should be performed in patients presenting with a low serum TSH [1]. Thyroid ultrasound should be performed in all those suspected or known to have a nodule to confirm the presence of a nodule, evaluate for additional nodules and cervical lymph nodes and assess for suspicious sonographic features. The next step in the evaluation of a thyroid nodule, if they meet the criteria as discussed later, is a fine needle aspiration (FNA) biopsy [12].

"Algorithm of thyroid nodule work up is presented at the end of the review (Fig. 1). 


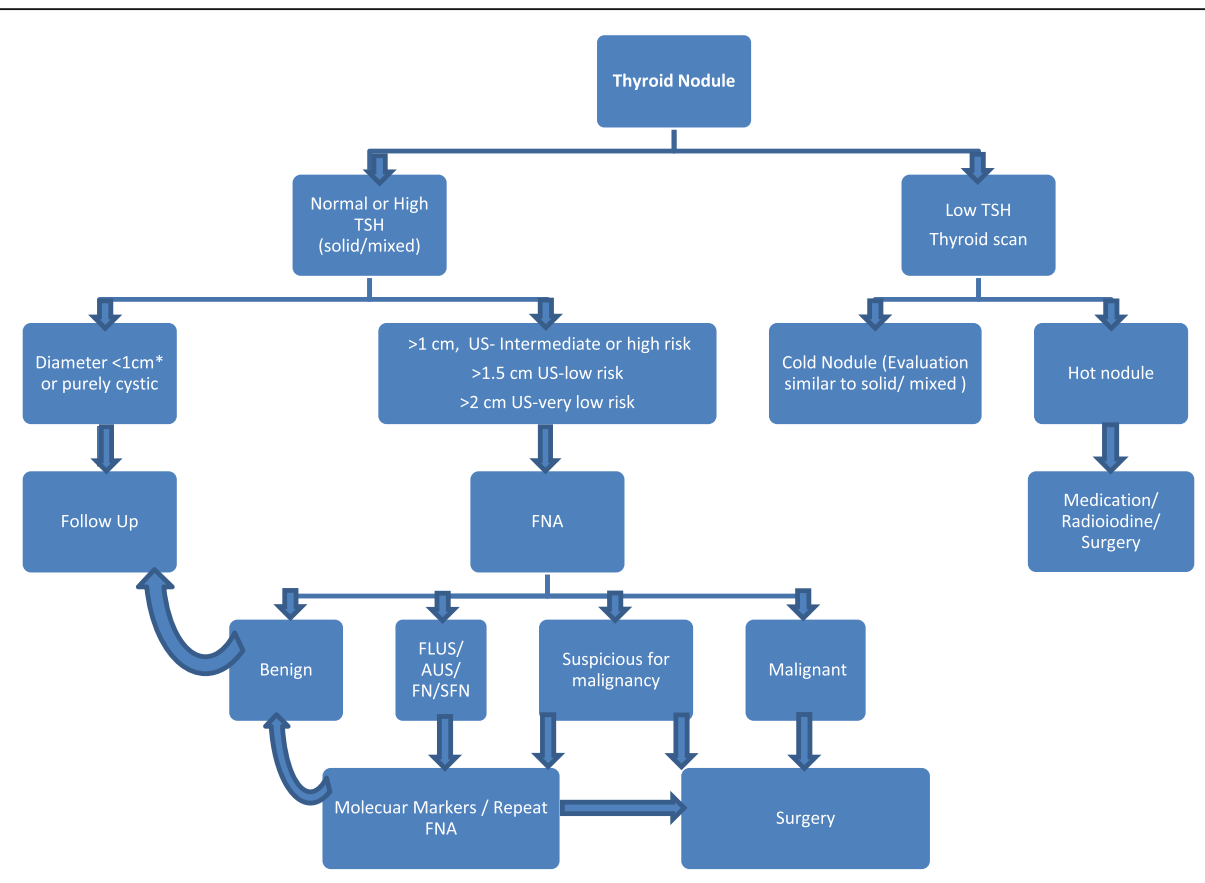

US- Ultrasound

FLUS- Follicular Lesion of Undetermined Significance

AUS- Atypia of Undetermined Significance

FN- Follicular Neoplasm

SFN- Suspicious of Follicular Neoplasm

* Some nodules $<1 \mathrm{~cm}$ may need FNA

Fig. 1 Thyroid Nodule Workup Algorithm

\section{History and physical examination}

Comprehensive history with focus on risk factors predicting malignancy (Table $1[1,3,13]$ ) should be part of the initial evaluation of a patient with thyroid nodule. Symptoms of hypothyroidism or hyperthyroidism should be assessed. Patients should be questioned about local

Table 1 Increased risk of malignancy in thyroid nodule on history and physical exam [1, 3, 13]

\footnotetext{
- History of childhood head/neck irradiation [113]

- Total body irradiation for bone marrow transplantation [114]

- Exposure to ionizing radiation from fallout in childhood or adolescence $[115,116]$

- Family history of PTC, MTC, or thyroid cancer syndrome (e.g., Cowden's syndrome, familial polyposis, Carney complex, multiple endocrine neoplasia [MEN] 2, Werner syndrome) [117]

- Enlarging nodule/rapid nodule growth

- Cervical lymphadenopathy

- Fixed nodule to surrounding tissue

- Vocal cord paralysis/hoarseness
}

pressure symptoms such as difficulty in swallowing or breathing, cough and change in voice.

Physical examination focusing on the thyroid gland assessing the volume and consistency and the nodular features such as size, number, location and consistency should be performed. Thyroid nodules that are smaller, usually $<1 \mathrm{~cm}$ and those located posteriorly or substernally will be difficult to palpate [14, 15]. Cervical lymph nodes should be assessed. Examination of signs of hypo or hyperthyroidism should be done.

\section{Laboratory tests Serum TSH}

Serum TSH should be measured in all patients with thyroid nodules. In patients with low TSH levels, radionuclide thyroid scan should be performed next to assess the functional status of the nodule. In a patient with a thyroid nodule, an increased serum TSH or TSH even in the upper limit of normal is associated with increased risk and an advanced stage of malignancy $[16,17]$. 


\section{Serum calcitonin}

In patients with thyroid nodules, the routine assessment of serum calcitonin is controversial and there are no definite recommendations for or against it $[1,18,19]$. Many prospective, non-randomized studies, mostly from outside US have assessed the value of measuring serum calcitonin [20-22]. The studies which show that use of serum calcitonin for screening may detect $\mathrm{C}$-cell hyperplasia and MTC at an earlier stage and overall survival may be improved, are based on pentagastrin stimulation testing to increase specificity. Pentagastrin is not available in the United States, and there is still an ambiguity about the sensitivity/specificity, threshold cut off values and costeffectiveness [22-24]. False-positive calcitonin results may be obtained in patients with hypercalcemia, hypergastrinemia, neuroendocrine tumors, renal insufficiency, papillary and follicular thyroid carcinomas, goiter, chronic autoimmune thyroiditis and prolonged use of certain medications $[12,25,26]$. False negative test result may be seen in rare MTCs that do not secrete calcitonin [27, 28].

\section{Serum thyroglobulin $(\mathrm{Tg})$}

In patients with thyroid nodules, routine measurement of serum thyroglobulin is not recommended as it can be elevated in many thyroid diseases and is neither specific nor sensitive for thyroid cancer $[29,30]$.

\section{Serum TPO antibodies}

Routine measurement of serum anti-thyroid peroxidase (TPO) antibodies is not necessary for thyroid nodule evaluation [31].

\section{Imaging studies}

\section{Radionuclide thyroid scan/scintigraphy}

In patients with thyroid nodule and a low serum TSH, suggesting overt or subclinical hyperthyroidism, the next step is to determine if the nodule is autonomously functioning. Thyroid scintigraphy is useful to determine the functional status of a nodule.

Scintigraphy, a diagnostic test used in nuclear medicine, utilizing iodine radioisotopes (more commonly used; usually $\left.{ }^{123} \mathrm{I}\right)$ or technetium pertechnetate $\left({ }^{99} \mathrm{Tc}\right)$, measures timed radioisotope uptake by the thyroid gland. The uptake of the radioisotopes will be greater in hyperfunctioning nodule and will be lower in most benign and virtually all malignant thyroid nodules than adjacent normal thyroid tissue [32-34].

Nodules may appear 'hot,' 'warm' or 'cold' depending on whether the tracer uptake is greater than, equal to or less than the surrounding normal thyroid tissue respectively [11]. Autonomous nodules may appear hot or indeterminate and account for 5 to $10 \%$ of palpable nodules. FNA evaluation of a hyperfunctioning nodule is not necessary as most hyperfunctioning nodules are benign [1].

\section{Thyroid sonography/ultrasound}

Thyroid Ultrasound (US) is a noninvasive imaging technique that should be performed on all patients with nodules suspected clinically or incidentally noted on other imaging studies such as carotid ultrasound, CT, MRI, or 18-FDG-PET scan.

Ultrasound will help confirm the thyroid nodule/s, assess the size, location and evaluate the composition, echogenicity, margins, presence of calcification, shape and vascularity of the nodules and the adjacent structures in the neck including the lymph nodes. If there are multiple nodules, all the nodules should be assessed for suspicious US characteristics.

FNA decision making is guided by both nodule size and ultrasound characteristics, the latter being more predictive of malignancy than size $[35,36]$. The nodular characteristics that are associated with a higher likelihood of malignancy include a shape that is taller than wide measured in the transverse dimension, hypoechogenicity, irregular margins, microcalcifications, and absent halo [35-41]. The feature with the highest diagnostic odds ratio for malignancy was suggested to be the nodule being taller than wider [42]. The more suspicious characteristics that the nodule has, it increases the likelihood of malignancy. In contrast, benign nodule predicting US characteristics include purely cystic nodule $(<2 \%$ risk of malignancy) [39], spongiform appearance ( $99.7 \%$ specific for benign thyroid nodule) [40, 42-44].

The recent ATA guidelines classify nodules into 5 risk groups based on US results [1]. However, the current AACE guidelines suggest a more practical, 3-tier risk classification: low risk, intermediate risk and high risk thyroid lesions, based on their US characteristics [13].

In patients with thyroid nodules and low TSH who have undergone thyroid scintigraphy, ultrasound is useful to check for concordance of the nodule and hyperfunctioning area on the scan, which do not need FNA and to evaluate other nonfunctional or intermediate nodules, which may require FNA based on sonographic criteria [1].

\section{Fine needle aspiration biopsy (FNA)}

FNA is considered the gold standard test for evaluating thyroid nodules. It is an office procedure, done under no or local anesthesia with 23 to 27 gauge needle, to obtain tissue samples for cytological examination. It is a safe, accurate and cost-effective way for evaluating thyroid nodules [45-54].

FNA can be done using palpation or with ultrasound guidance. US machines (7.5 to $10 \mathrm{MHz}$ transducers), provide clear and continuous visualization of thyroid gland and allow for real time visualization of the needle tip to ensure accurate sampling. Ultrasound guided technique has lower nondiagnostic and false negative 
cytology rates compared to palpation technique $[48,55]$. US guided FNA is preferred for difficult to palpate nodules, predominantly cystic or posteriorly located nodules [1]. In practice more clinicians are using ultrasound guided FNA (either free hand technique or with the help of a needle guide) over palpation guided technique for all thyroid FNA.

\section{Indications for FNA}

Over the years there has been a change in guidelines with regards to judiciously selecting the thyroid nodules for further evaluation with FNA. The approach has been toward a conservative direction. The changes are reflected in the recently published ATA guidelines [1] (Table 2).

FNA should not be performed on thyroid nodules $<1 \mathrm{~cm}$ in diameter with some exceptions discussed later in this section. For nodules $>1 \mathrm{~cm}$, FNA is recommended to further evaluate the thyroid nodule with some exceptions [1].

FNA biopsy is recommended for nodules $>1 \mathrm{~cm}$ with high suspicion features (solid hypoechoic nodule or solid hypoechoic component of a partially cystic nodule with either one or more of features: irregular margin or microcalcification or taller than wide shape or rim calcification or evidence of extra thyroidal extension; estimated malignancy risk of 70-90\%) or $>1 \mathrm{~cm}$ with intermediate suspicion features (hypoechoic solid nodule with smooth margins without microcalcification, extra thyroidal extension or taller than wide shape; estimated malignancy risk 10-20\%). Low suspicion features include isoechoic or hyperechoic solid nodule or partially cystic nodules with eccentric solid areas without the features of highly suspicious nodule (estimated malignancy risk of 5-10\%). Cyst drainage may also be performed, especially in symptomatic patients. Very low suspicion features include spongiform (aggregation of multiple microcystic components in more than $50 \%$ of the nodule volume $[40,52])$ or partially cystic nodules without the features of the above mentioned suspicious category features (estimated malignancy risk of $<3 \%$ ).

Cervical lymph node assessment (anterior, central and lateral compartment) should be performed in all patients

Table 2 Recommendations for diagnostic FNA based on size and US features $[1,35-37,85,86,118-120]$

A. Nodules $\geq 1 \mathrm{~cm}$ with intermediate or high suspicion US pattern

B. Nodules $\geq 1.5 \mathrm{~cm}$ with low suspicion US pattern

C. Nodules $\geq 2 \mathrm{~cm}$ with very low suspicion US pattern (e.g., spongiform). Observation an alternate option.

D. For nodules that do not meet the above criteria, FNA is not required, including nodules $<1 \mathrm{~cm}$ (with some exceptions) and purely cystic nodules.

ATA Guidelines 2015 with thyroid nodule. Suspicious lymph nodes (microcalcification, cystic, peripheral vascularity, hyperechogenicity, round shape [56]) should have FNA evaluation for cytology and washout Tg measurement. This is one of the scenarios where a subcentimeter thyroid nodule associated with these abnormal cervical lymph nodes should undergo FNA. Also in patients with the clinical risk factors mentioned in Table 1 and with the high pretest likelihood for thyroid cancer associated with these features, FNA at sizes lower than those recommended can be considered $[1,13]$. PET positive nodules have a higher incidence of malignancy $\sim 40-45 \%$ and FNA is recommended in nodules $>1 \mathrm{~cm}[1,57,58]$.

The US features of each nodule should be assessed independently to determine the need for FNA biopsy. The nodules that are not biopsied should be monitored with periodic US with follow up duration and frequency based on factors including sonographic features and risk factors. Also conservative approach of active surveillance without FNA may be reasonable approach for patients who meet the above FNA criteria but are at high surgical risk and those with relatively short life expectancy [1].

\section{Cytological diagnosis}

FNA cytology of the thyroid nodule is reported using various classification systems. In US, the Bethesda System for Reporting Thyroid Cytopathology is the most commonly used. The diagnostic groups suggested are [59, 60]:

Benign - This includes macrofollicular or adenomatoid/hyperplastic nodules, colloid adenomas (most common), nodular goiter, lymphocytic and granulomatous thyroiditis. $0-3 \%$ predicted risk of malignancy.

Follicular lesion or atypia of undetermined significance (FLUS or AUS) - This includes lesions with atypical cells, or mixed macro- and microfollicular nodules. 5-15\% predicted risk of malignancy.

Follicular neoplasm or suspicious for a follicular neoplasm (FN/SFN) - This includes microfollicular nodules, including Hurthle cell lesions/ suspicious for Hurthle cell neoplasm. 15-30 \% predicted risk of malignancy.

Suspicious for malignancy. $60-75 \%$ predicted risk of malignancy.

Malignant. This includes PTC (most common), MTC, anaplastic carcinoma, and high-grade metastatic cancers. 97-99 \% predicted risk for malignancy.

Nondiagnostic or Unsatisfactory. 1-4 \% predicted risk of malignancy.

Other classification systems such as UK-RCPath (Royal College of Pathology) or Italian AME Consensus and modifications of these systems are also used to report 
cytology results [13]. The interpretation of the FNA smears is influenced by the expertise of the cytopathologist and there is inherent limitation to the reproducibility of the cytopathological results $[45,46,61,62]$. Accuracy of the results is also influenced by the skill of the operator, FNA technique and specimen preparation. FNA results are categorized as either diagnostic/satisfactory, if it contains at least six groups, each containing of at least 10 well-preserved thyroid epithelial cells, else nondiagnostic/unsatisfactory $[11,13]$. FNA results are crucial in guiding the further steps in the management of thyroid nodule.

Benign cytology ( $70 \%$ of all FNAs) is the most common finding on FNA $[13,45,48]$. Indeterminate results ( $10-15 \%$ of all FNAs), which are without a distinct cytological diagnosis [45, 46, 63], include the diagnostic groups of FLUS/AUS and FN/SFN. This diagnostic group possesses a challenge in terms of next steps for management. In practice, although the majority of these patients undergo surgery, the majority of the nodules are found benign. Molecular tests have been developed in an attempt to determine whether an indeterminate nodule is benign or malignant.

Nondiagnostic or unsatisfactory smears $(\sim 15 \%$ of all FNAs) have inadequate number of cells to make a diagnosis and result from cystic fluid without cells, bloody smears, or improper techniques in preparing slides [11, 64-67].

\section{Molecular markers}

The use of molecular markers in thyroid nodules has been suggested for diagnostic purpose in case of indeterminate cytological diagnosis, to assist with decision making about management option (surgical treatment). These tests are performed using samples from needle washings collected during fine needle aspiration biopsy. The molecular tests which have the most available data are: Afirma Gene-expression Classifier [68], seven-gene panel of genetic mutations and rearrangements [69] and galectin-3 immunohistochemistry [70].

The Afirma gene-expression classifier (167 GEC; mRNA expression of 167 genes) evaluates for the presence of benign gene expression profile. It has a high sensitivity (92\%) and negative predictive (93\%) value but low positive predictive value and specificity $(48-53 \%)[68,71]$. It is used as a rule out test to identify benign nodules. A benign GEC result predicts low risk of malignancy but the nodules classified as benign still have $\sim 5 \%$ risk of malignancy $[71,72]$.

The seven gene mutation and rearrangement analysis panel evaluates for BRAF, NRAS, HRAS and KRAS point mutations and common rearrangements of RET/PTC and PAX8/PPAR $\gamma$. It has a high specificity (86-100 \%) and positive predictive value (84-100 \%) but poor sensitivity (reported from 44 to $100 \%$ ) [69, 73-75]. It is being used as a rule in test for thyroid malignancy.

This field is evolving and many other molecular tests are being developed (mRNA markers, miRNA markers, etc.) [70, 76-80]. None of the available tests can decisively confirm the presence or absence of malignancy in all indeterminate thyroid nodules. Long term data are needed to confirm its utility in clinical practice. Most of the assays are trained on classic papillary cancers and have limited data in follicular cancers. One has to consider performance of a diagnostic test based on prevalence of the disease (cancer); at high cancer prevalence rate, NPV falls dramatically. Tests are expensive and in deciding their use in management of indeterminate nodules, one should also consider the pretest probability of malignancy with clinical risk features, sonographic characteristics and the size of the nodule, the degree of patient concern and patient preferences, and if the patient would be able to come back for a follow up. In the current settings, molecular testing should only be used to supplement cytopathologic evaluation or clinical and imaging assessment [81]. Patients should be counselled regarding the current clinical utility and limitations of these tests. The AACE Guidelines recommend neither for nor against their use in clinical practice [13]. This field is new and evolving, the recommendations of the use of these molecular tests can be expected to change in the future.

\section{Management}

Various factors including serum TSH, clinical risk factor assessment, size of the nodule, ultrasound characteristics, patient preferences and results of the FNA biopsy should be considered in management of thyroid nodule. FNA biopsy cytological diagnosis is the most crucial determinant in decision making.

For autonomous or hyperfunctioning nodules, if the patient has hyperthyroidism, management options include radioiodine therapy or surgery. If the patient has subclinical hyperthyroidism (low TSH with normal FT4), management depends on clinical risk of complications (atrial fibrillation in patients over the age of 60 to 65 years and osteoporosis in postmenopausal women) and the degree of TSH suppression [82-84].

Nodules less than $1 \mathrm{~cm}$ with some exceptions should not be biopsied and followed up closely [1]. Also for these patients the frequency and duration of follow up will depend on the additional risk factors present.

For nodules selected for FNA, management primarily depends on cytologic results. According to the Bethesda Classification scheme, FNA of the nodules yields six major results with subsequent different management for each category. However the management of indeterminate nodules (FLUS/AUS and FN/SFN) has similar principles and will be discussed together. 


\section{Nodules with benign cytology}

The risk of malignancy in nodules reported as benign is 0-3 \% [85-88]. Patients with benign nodules are usually managed conservatively without surgery; immediate further diagnostic studies are not required [1]. Though there is a risk of false negative results associated with cytology reporting, initial benign FNA has negligible mortality risk in long term follow up [89].

The frequency and duration of follow up of the benign nodules have been variable in clinical practice. In the nodules that have suddenly enlarged, hemorrhage and cystic degeneration is the most common cause; malignancy is rare even in nodules that have grown $[90,91]$. There is no clear evidence to suggest that nodules with larger size $(>3$ or $4 \mathrm{~cm})$ with benign cytology should be managed differently than smaller nodules $[62,92]$. The follow up of the benign cytological diagnosis should be decided on the sonographic characteristic of the nodule rather than growth $[93,94]$.

Per the 2015 ATA guidelines, nodules with high suspicious US pattern should have repeat US and FNA within 12 months; while those with low to intermediate suspicious US pattern should have repeat US in 12-24 months. The decision to repeat FNA or observe with repeat US is based on $>20 \%$ growth in at least 2 nodule dimensions or $>50 \%$ increase in nodule volume or the appearance of new suspicious US pattern. Nodules with very low suspicious patterns should have US repeated at 24 months or more. Continued surveillance for a nodule with repeat second benign cytology is not needed $[1,95]$.

Surgical removal may be needed for benign nodules if they are causing pressure or structural symptoms. TSH suppressive therapy has no role in the management of benign nodule. Percutaneous ethanol ablation can be considered for thyroid cysts and certain complex thyroid nodules [13].

\section{Indeterminate nodules (FLUS/ AUS or FN/SFN)}

FLUS/AUS and FN/SFN have 5-15\% and 15-30\% predicted risk of malignancy, respectively. Practice pattern vary considerably in management of indeterminate nodules [96]. Molecular tests have impacted the management strategies in this category. The clinical risk factors, US characteristics (Elastography in addition can be considered in these cases), patient preference and availability/feasibility of the molecular tests should be considered in the decision making process. Some scores such as Mcgill thyroid nodule scores have been tried in pre-operative decision making in thyroid nodules [97].

FLUS/AUS category includes lesions with focal architecture or nuclear atypia whose significance cannot be further determined and specimens that are limited because of poor fixation or obscuring blood [98]. The interpretation of the features which comprise this category is based entirely on the observer which results in poor reproducibility and a second review by experienced high volume cytopathologist can be considered [99, 100]. Repeat FNA or molecular testing (extra sample can be collected at the time of initial testing) can be considered to supplement the malignancy risk assessment $[68,69$, $101,102]$. If either of them is not performed or inconclusive, based on clinical and US risk factors and patient preference, either surveillance with repeat US or diagnostic surgery can be chosen [1]. With the new developments in molecular testing, the approach to this category may change in the future.

For FN/SFN, surgical excision for diagnosis had been an established practice. With the molecular testing being available, it can be used to supplement the malignancy risk assessment again after considering the clinical and US risk factors and patient preference $[68,103]$. If the molecular testing is not available/performed or inconclusive, diagnostic surgical excision can be considered. Patients with surgical histology specimens showing benign follicular adenoma (absence of capsular or vascular invasion) do not require further treatment. However, patients whose surgical histology shows follicular thyroid cancer might need to have a completion thyroidectomy $[1,13,69]$.

\section{Suspicious for malignancy}

This category includes specimens strongly suspicious for malignancy, but lacking diagnostic criteria [60]. Diagnostic surgery and histologic exam would be needed in most of the cases. For nodules with the cytology reported as suspicious for malignancy, after consideration of clinical and US risk factors and patient preference, molecular tests (seven-gene mutation and rearrangement panel) can be considered if it would alter the surgical decision making, which is the recommended modality of management $[1,69,104]$.

As more data become available on the molecular tests, the management of this category may potentially change in the future.

\section{Malignant}

This category includes papillary cancer, follicular carcinoma, Hurthle cell (oncocytic) carcinoma, medullary cancer, thyroid lymphoma, anaplastic cancer, and cancer metastatic to the thyroid. Surgery is generally recommended for these patients $[1,13,105,106]$. Circumstances in which active surveillance may be considered include low risk papillary microcarcinoma $(<1 \mathrm{~cm})$, patients with high surgical risk, short life expectancy and if concurrent surgical or medical issues need to be addressed first. For cancer due to metastasis, further investigations to find the primary lesion should be undertaken. 


\section{Nondiagnostic}

This category includes cytologically inadequate specimen. If no or scant follicular tissue is obtained, the absence of malignant cells does not mean a negative biopsy in patients with nondiagnostic FNA. In such cases, FNA using US-guidance should be repeated and if possible with onsite cytological assessment $[1,13,107]$. If the results are still nondiagnostic, core needle biopsy or close observation or diagnostic surgical excision can be considered depending on the suspicious pattern on sonography, clinical risk factors and growth of the nodule during active surveillance $[1,108,109]$.

\section{Pregnancy}

The evaluation of a thyroid nodule in a pregnant woman should be done in same way as one would in nonpregnant state. However, for the pregnant women with nodule and suppressed TSH that persists after first trimester, further evaluation can be delayed after pregnancy and cessation of lactation when the radionuclide scan can be performed. For a nodule with FNA suggesting PTC, if it is discovered early in pregnancy and if it grows substantially (20\% growth in at least 2 dimensions or $50 \%$ increase in volume or new suspicious US pattern) by 24 weeks gestation or if suspicious cervical lymph nodes are noted on US, surgery should be considered during the second trimester of pregnancy. However, if it is diagnosed in the latter half of the pregnancy or if it is diagnosed early in the pregnancy and remains stable by midgestation, surgery may be performed after delivery. Consideration could be given to administration of levothyroxine therapy to keep the TSH in the range of $0.1-1 \mathrm{mU} / \mathrm{L}[1,13,110-112]$.

\section{Conclusions}

Thyroid nodules are common and carry a 4-6.5 \% risk of malignancy. The initial evaluation in all patients with a thyroid nodule includes a detailed history and physical examination assessing risk factors, measurement of serum TSH and neck ultrasonography to assess the size and suspicious characteristics. Fine needle aspiration (FNA) biopsy is an accurate and cost effective way to evaluate thyroid nodules. Nodules with diameter $<1 \mathrm{~cm}$ with some exceptions require no FNA and can be observed with a follow up US. Patients with benign nodules are usually followed without surgery. Where available, mRNA classifier system or mutational analysis can be used for further evaluating FNA aspirates with cytology of follicular neoplasm or follicular lesion/ atypia of undetermined significance. Patients with cytology suggesting cancer should be referred for surgery. The high prevalence and increasing diagnosis of incidental thyroid nodules requires clinicians to adopt evidence-based approaches to evaluate, risk stratify and provide appropriate treatment. As more evidence becomes available, active surveillance may become possible for selected cases of thyroid cancer patients.

\section{Acknowledgements \\ Not applicable.}

Funding

No funding sources.

Availability of data and materials

Not applicable.

\section{Authors' contributions}

ST was involved in literature search/review and formulation and writing the manuscript. HG provided guidance regarding the literature. HG also assisted with manuscript writing/review. All authors read and approved the final manuscript.

\section{Competing interests}

The authors declare that they have no competing interests.

\section{Consent for publication}

Not applicable.

\section{Ethics approval and consent to participate}

Not applicable.

Received: 21 July 2016 Accepted: 26 September 2016

Published online: 03 October 2016

\section{References}

1. Haugen BR, Alexander EK, Bible KC, et al. 2015 American Thyroid Association Management Guidelines for Adult Patients with Thyroid Nodules and Differentiated Thyroid Cancer: The American Thyroid Association Guidelines Task Force on Thyroid Nodules and Differentiated Thyroid Cancer. Thyroid. 2016;26(1):1-133.

2. Tunbridge WM, Evered DC, Hall R, et al. The spectrum of thyroid disease in a community: the Whickham survey. Clin Endocrinol (Oxf). 1977;7(6):481-93.

3. Hegedus L. Clinical practice. The thyroid nodule. N Engl J Med. 2004; 351(17):1764-71.

4. Dean DS, Gharib H. Epidemiology of thyroid nodules. Best Pract Res Clin Endocrinol Metab. 2008;22(6):901-11.

5. Davies L, Welch HG. Current thyroid cancer trends in the United States. JAMA Otolaryngol Head Neck Surg. 2014;140(4):317-22.

6. Li N, Du XL, Reitzel LR, Xu L, Sturgis EM. Impact of enhanced detection on the increase in thyroid cancer incidence in the United States: review of incidence trends by socioeconomic status within the surveillance, epidemiology, and end results registry, 1980-2008. Thyroid. 2013;23(1):103-10.

7. Werk Jr EE, Vernon BM, Gonzalez JJ, Ungaro PC, McCoy RC. Cancer in thyroid nodules. A community hospital survey. Arch Intern Med. 1984;144(3):474-6.

8. Belfiore A, Giuffrida D, La Rosa GL, et al. High frequency of cancer in cold thyroid nodules occurring at young age. Acta Endocrinol (Copenh). 1989;121(2):197-202.

9. Lin JD, Chao TC, Huang BY, Chen ST, Chang HY, Hsueh C. Thyroid cancer in the thyroid nodules evaluated by ultrasonography and fine-needle aspiration cytology. Thyroid. 2005;15(7):708-17.

10. Tan GH, Gharib H. Thyroid incidentalomas: management approaches to nonpalpable nodules discovered incidentally on thyroid imaging. Ann Intern Med. 1997;126(3):226-31.

11. Gharib H, Papini E. Thyroid nodules: clinical importance, assessment, and treatment. Endocrinol Metab Clin North Am. 2007;36(3):707-35. vi.

12. Castro MR, Gharib H. Continuing controversies in the management of thyroid nodules. Ann Intern Med. 2005;142(11):926-31.

13. Gharib H, Papini E, Garber JR, et al. American Association of Clinical Endocrinologists, American College of Endocrinology, and Associazione Medici Endocrinologi Medical Guidelines for Clinical Practice for the Diagnosis and Management of Thyroid Nodules - 2016 Update. Endocr Pract. 2016;22(5):622-39.

14. Tan GH, Gharib H, Reading CC. Solitary thyroid nodule. Comparison between palpation and ultrasonography. Arch Intern Med. 1995;155(22):2418-23. 
15. Singh S, Singh A, Khanna AK. Thyroid incidentaloma. Indian J Surg Oncol. 2012;3(3):173-81.

16. Boelaert K, Horacek J, Holder RL, Watkinson JC, Sheppard MC, Franklyn JA. Serum thyrotropin concentration as a novel predictor of malignancy in thyroid nodules investigated by fine-needle aspiration. J Clin Endocrinol Metab. 2006;91(11):4295-301.

17. Haymart MR, Repplinger DJ, Leverson GE, et al. Higher serum thyroid stimulating hormone level in thyroid nodule patients is associated with greater risks of differentiated thyroid cancer and advanced tumor stage. J Clin Endocrinol Metab. 2008:93(3):809-14.

18. Costante G, Filetti $\mathrm{S}$. Early diagnosis of medullary thyroid carcinoma: is systematic calcitonin screening appropriate in patients with nodular thyroid disease? Oncologist. 2011;16(1):49-52.

19. Gharib H, Papini E, Paschke R. Thyroid nodules: a review of current guidelines, practices, and prospects. Eur J Endocrinol. 2008;159(5):493-505.

20. Elisei R, Bottici V, Luchetti F, et al. Impact of routine measurement of serum calcitonin on the diagnosis and outcome of medullary thyroid cancer: experience in 10,864 patients with nodular thyroid disorders. J Clin Endocrinol Metab. 2004;89(1):163-8.

21. Niccoli P, Wion-Barbot N, Caron P, et al. Interest of routine measurement of serum calcitonin: study in a large series of thyroidectomized patients. The French Medullary Study Group. J Clin Endocrinol Metab. 1997;82(2):338-41.

22. Costante G, Meringolo D, Durante $C$, et al. Predictive value of serum calcitonin levels for preoperative diagnosis of medullary thyroid carcinoma in a cohort of 5817 consecutive patients with thyroid nodules. J Clin Endocrinol Metab. 2007:92(2):450-5.

23. Machens A, Hoffmann F, Sekulla C, Dralle H. Importance of gender-specific calcitonin thresholds in screening for occult sporadic medullary thyroid cancer. Endocr Relat Cancer. 2009;16(4):1291-8.

24. Chambon G, Alovisetti C, Idoux-Louche C, et al. The use of preoperative routine measurement of basal serum thyrocalcitonin in candidates for thyroidectomy due to nodular thyroid disorders: results from 2733 consecutive patients. J Clin Endocrinol Metab. 2011;96(1):75-81.

25. Toledo SP, Lourenco Jr DM, Santos MA, Tavares MR, Toledo RA, CorreiaDeur JE. Hypercalcitoninemia is not pathognomonic of medullary thyroid carcinoma. Clinics (Sao Paulo). 2009;64(7):699-706.

26. Erdogan MF, Gursoy A, Kulaksizoglu M. Long-term effects of elevated gastrin levels on calcitonin secretion. J Endocrinol Invest. 2006;29(9):771-5.

27. Wang TS, Ocal IT, Sosa JA, Cox H, Roman S. Medullary thyroid carcinoma without marked elevation of calcitonin: a diagnostic and surveillance dilemma. Thyroid. 2008;18(8):889-94.

28. Dora JM, Canalli MH, Capp C, Punales MK, Vieira JG, Maia AL. Normal perioperative serum calcitonin levels in patients with advanced medullary thyroid carcinoma: case report and review of the literature. Thyroid. 2008;18(8):895-9.

29. Suh I, Vriens MR, Guerrero MA, et al. Serum thyroglobulin is a poor diagnostic biomarker of malignancy in follicular and Hurthle-cell neoplasms of the thyroid. Am J Surg. 2010;200(1):41-6.

30. Lee EK, Chung KW, Min HS, et al. Preoperative serum thyroglobulin as a useful predictive marker to differentiate follicular thyroid cancer from benign nodules in indeterminate nodules. J Korean Med Sci. 2012;27(9):1014-8.

31. Repplinger D, Bargren A, Zhang YW, Adler JT, Haymart M, Chen H. Is Hashimoto's thyroiditis a risk factor for papillary thyroid cancer? J Surg Res. 2008;150(1):49-52.

32. Shambaugh 3rd GE, Quinn JL, Oyasu R, Freinkel N. Disparate thyroid imaging. Combined studies with sodium pertechnetate Tc $99 \mathrm{~m}$ and radioactive iodine. Jama. 1974;228(7):866-9.

33. Blum M, Goldman AB. Improved diagnosis of "nondelineated" thyroid nodules by oblique scintillation scanning and echography. J Nucl Med. 1975;16(8):713-5.

34. Reschini E, Ferrari C, Castellani M, et al. The trapping-only nodules of the thyroid gland: prevalence study. Thyroid. 2006;16(8):757-62.

35. Leenhardt L, Hejblum G, Franc B, et al. Indications and limits of ultrasoundguided cytology in the management of nonpalpable thyroid nodules. J Clin Endocrinol Metab. 1999;84(1):24-8.

36. Papini E, Guglielmi R, Bianchini A, et al. Risk of malignancy in nonpalpable thyroid nodules: predictive value of ultrasound and color-Doppler features J Clin Endocrinol Metab. 2002;87(5):1941-6.

37. Nam-Goong IS, Kim HY, Gong G, et al. Ultrasonography-guided fine-needle aspiration of thyroid incidentaloma: correlation with pathological findings. Clin Endocrinol (Oxf). 2004;60(1):21-8.
38. Cappelli C, Castellano M, Pirola I, et al. The predictive value of ultrasound findings in the management of thyroid nodules. QJM. 2007;100(1):29-35.

39. Frates MC, Benson CB, Doubilet PM, et al. Prevalence and distribution of carcinoma in patients with solitary and multiple thyroid nodules on sonography. J Clin Endocrinol Metab. 2006;91(9):3411-7.

40. Moon WJ, Jung SL, Lee JH, et al. Benign and malignant thyroid nodules: US differentiation-multicenter retrospective study. Radiology. 2008;247(3):762-70.

41. Remonti LR, Kramer CK, Leitao CB, Pinto LC, Gross JL. Thyroid ultrasound features and risk of carcinoma: a systematic review and meta-analysis of observational studies. Thyroid. 2015;25(5):538-50.

42. Brito JP, Gionfriddo MR, Al Nofal A, et al. The accuracy of thyroid nodule ultrasound to predict thyroid cancer: systematic review and meta-analysis. J Clin Endocrinol Metab. 2014;99(4):1253-63.

43. Bonavita JA, Mayo J, Babb J, et al. Pattern recognition of benign nodules at ultrasound of the thyroid: which nodules can be left alone? AJR Am J Roentgenol. 2009;193(1):207-13.

44. Moon WJ, Kwag HJ, Na DG. Are there any specific ultrasound findings of nodular hyperplasia ("leave me alone" lesion) to differentiate it from follicular adenoma? Acta Radiol. 2009;50(4):383-8.

45. Gharib H. Fine-needle aspiration biopsy of thyroid nodules: advantages, limitations, and effect. Mayo Clin Proc. 1994:69(1):44-9.

46. Gharib H, Goellner JR. Fine-needle aspiration biopsy of thyroid nodules. Endocr Pract. 1995; 1(6):410-7.

47. Bomeli SR, LeBeau SO, Ferris RL. Evaluation of a thyroid nodule. Otolaryngol Clin North Am. 2010;43(2):229-38. vii.

48. Castro MR, Gharib H. Thyroid fine-needle aspiration biopsy: progress, practice, and pitfalls. Endocr Pract. 2003;9(2):128-36.

49. Jeffrey PB, Miller TR. Fine-needle aspiration cytology of the thyroid. Pathology (Phila). 1996;4(2):319-35.

50. Hamberger B, Gharib H, Melton 3rd LJ, Goellner JR, Zinsmeister AR. Fineneedle aspiration biopsy of thyroid nodules. Impact on thyroid practice and cost of care. Am J Med. 1982;73(3):381-4.

51. Hamburger Jl, Hamburger SW. Fine needle biopsy of thyroid nodules: avoiding the pitfalls. N Y State J Med. 1986;86(5):241-9.

52. Sakorafas GH. Thyroid nodules; interpretation and importance of fine-needle aspiration (FNA) for the clinician - practical considerations. Surg Oncol. 2010;19(4):e130-9.

53. Can AS. Cost-effectiveness comparison between palpation- and ultrasoundguided thyroid fine-needle aspiration biopsies. BMC Endocr Disord. 2009;9:14.

54. Singh Ospina N, Brito JP, Maraka S, et al. Diagnostic accuracy of ultrasoundguided fine needle aspiration biopsy for thyroid malignancy: systematic review and meta-analysis. Endocrine. 2016;53:651-61.

55. Danese D, Sciacchitano S, Farsetti A, Andreoli M, Pontecorvi A. Diagnostic accuracy of conventional versus sonography-guided fine-needle aspiration biopsy of thyroid nodules. Thyroid. 1998;8(1):15-21.

56. Leenhardt L, Erdogan MF, Hegedus L, et al. 2013 European thyroid association guidelines for cervical ultrasound scan and ultrasound-guided techniques in the postoperative management of patients with thyroid cancer. Eur Thyroid J. 2013;2(3):147-59.

57. Yoon JH, Cho A, Lee HS, Kim EK, Moon HJ, Kwak JY. Thyroid incidentalomas detected on 18 F-fluorodeoxyglucose-positron emission tomography/ computed tomography: Thyroid Imaging Reporting and Data System (TIRADS) in the diagnosis and management of patients. Surgery. 2015; 158(5):1314-22.

58. Flukes S, Lenzo N, Moschilla G, Sader C. Positron emission tomographypositive thyroid nodules: rate of malignancy and histological features. ANZ J Surg. 2016;86(6):487-91.

59. Baloch ZW, LiVolsi VA, Asa SL, et al. Diagnostic terminology and morphologic criteria for cytologic diagnosis of thyroid lesions: a synopsis of the National Cancer Institute Thyroid Fine-Needle Aspiration State of the Science Conference. Diagn Cytopathol. 2008;36(6):425-37.

60. Cibas ES, Ali SZ. The Bethesda System for Reporting Thyroid Cytopathology. Thyroid. 2009;19(11):1159-65.

61. Gharib H, Goellner JR. Fine-needle aspiration biopsy of the thyroid: an appraisal. Ann Intern Med. 1993;1 18(4):282-9.

62. Pinchot SN, Al-Wagih H, Schaefer S, Sippel R, Chen H. Accuracy of fineneedle aspiration biopsy for predicting neoplasm or carcinoma in thyroid nodules $4 \mathrm{~cm}$ or larger. Arch Surg. 2009;144(7):649-55.

63. Cersosimo E, Gharib H, Suman VJ, Goellner JR. "Suspicious" thyroid cytologic findings: outcome in patients without immediate surgical treatment. Mayo Clin Proc. 1993;68(4):343-8. 
64. Gharib H, Goellner JR, Zinsmeister AR, Grant CS, Van Heerden JA. Fine-needle aspiration biopsy of the thyroid. The problem of suspicious cytologic findings. Ann Intern Med. 1984;101(1):25-8.

65. Chow LS, Gharib H, Goellner JR, van Heerden JA. Nondiagnostic thyroid fine-needle aspiration cytology: management dilemmas. Thyroid. 2001; 11(12):1147-51.

66. Schmidt T, Riggs MW, Speights Jr VO. Significance of nondiagnostic fineneedle aspiration of the thyroid. South Med J. 1997:90(12):1183-6.

67. McHenry CR, Walfish PG, Rosen IB. Non-diagnostic fine needle aspiration biopsy: a dilemma in management of nodular thyroid disease. Am Surg. 1993;59(7):415-9.

68. Alexander EK, Kennedy GC, Baloch ZW, et al. Preoperative diagnosis of benign thyroid nodules with indeterminate cytology. N Engl J Med. 2012;367(8):705-15.

69. Nikiforov YE, Ohori NP, Hodak SP, et al. Impact of mutational testing on the diagnosis and management of patients with cytologically indeterminate thyroid nodules: a prospective analysis of 1056 FNA samples. J Clin Endocrinol Metab. 2011:96(11):3390-7.

70. Bartolazzi A, Orlandi F, Saggiorato E, et al. Galectin-3-expression analysis in the surgical selection of follicular thyroid nodules with indeterminate fineneedle aspiration cytology: a prospective multicentre study. Lancet Oncol. 2008:9(6):543-9.

71. Alexander EK, Schorr M, Klopper J, et al. Multicenter clinical experience with the Afirma gene expression classifier. J Clin Endocrinol Metab. 2014;99(1):119-25.

72. Marti JL, Avadhani V, Donatelli LA, et al. Wide Inter-institutional Variation in Performance of a Molecular Classifier for Indeterminate Thyroid Nodules. Ann Surg Oncol. 2015;22(12):3996-4001.

73. Cantara S, Capezzone M, Marchisotta S, et al. Impact of proto-oncogene mutation detection in cytological specimens from thyroid nodules improves the diagnostic accuracy of cytology. J Clin Endocrinol Metab. 2010;95(3):1365-9.

74. Nikiforov YE, Steward DL, Robinson-Smith TM, et al. Molecular testing for mutations in improving the fine-needle aspiration diagnosis of thyroid nodules. J Clin Endocrinol Metab. 2009;94(6):2092-8.

75. Beaudenon-Huibregtse S, Alexander EK, Guttler RB, et al. Centralized molecular testing for oncogenic gene mutations complements the local cytopathologic diagnosis of thyroid nodules. Thyroid. 2014;24(10):1479-87.

76. Franco C, Martinez V, Allamand JP, et al. Molecular markers in thyroid fineneedle aspiration biopsy: a prospective study. Appl Immunohistochem Mol Morphol. 2009;17(3):211-5.

77. Fadda G, Rossi ED, Raffaelli M, et al. Follicular thyroid neoplasms can be classified as low- and high-risk according to HBME-1 and Galectin-3 expression on liquid-based fine-needle cytology. Eur J Endocrinol. 2011;165(3):447-53.

78. Prasad NB, Somervell $H$, Tufano RP, et al. Identification of genes differentially expressed in benign versus malignant thyroid tumors. Clin Cancer Res. 2008;14(11):3327-37

79. Nikiforova MN, Tseng GC, Steward D, Diorio D, Nikiforov YE. MicroRNA expression profiling of thyroid tumors: biological significance and diagnostic utility. J Clin Endocrinol Metab. 2008;93(5):1600-8.

80. Agretti $P$, Ferrarini $E$, Rago $T$, et al. MicroRNA expression profile helps to distinguish benign nodules from papillary thyroid carcinomas starting from cells of fine-needle aspiration. Eur J Endocrinol. 2012;167(3):393-400.

81. Bernet V, Hupart KH, Parangi S, Woeber KA. AACE/ACE disease state commentary: molecular diagnostic testing of thyroid nodules with indeterminate cytopathology. Endocr Pract. 2014;20(4):360-3.

82. Bauer DC, Rodondi N, Stone KL, Hillier TA. Thyroid hormone use, hyperthyroidism and mortality in older women. Am J Med. 2007;120(4):343-9.

83. Auer J, Scheibner P, Mische T, Langsteger W, Eber O, Eber B. Subclinical hyperthyroidism as a risk factor for atrial fibrillation. Am Heart J. 2001; 142(5):838-42.

84. Biondi B, Cooper DS. The clinical significance of subclinical thyroid dysfunction. Endocr Rev. 2008:29(1):76-131.

85. Orlandi A, Puscar A, Capriata E, Fideleff H. Repeated fine-needle aspiration of the thyroid in benign nodular thyroid disease: critical evaluation of long-term follow-up. Thyroid. 2005;15(3):274-8

86. Illouz F, Rodien P, Saint-Andre JP, et al. Usefulness of repeated fine-needle cytology in the follow-up of non-operated thyroid nodules. Eur J Endocrinol. 2007;156(3):303-8.

87. Oertel YC, Miyahara-Felipe L, Mendoza MG, Yu K. Value of repeated fine needle aspirations of the thyroid: an analysis of over ten thousand FNAs. Thyroid. 2007;17(11):1061-6.
88. Tee YY, Lowe AJ, Brand CA, Judson RT. Fine-needle aspiration may miss a third of all malignancy in palpable thyroid nodules: a comprehensive literature review. Ann Surg. 2007;246(5):714-20.

89. Nou E, Kwong N, Alexander LK, Cibas ES, Marqusee E, Alexander EK. Determination of the optimal time interval for repeat evaluation after a benign thyroid nodule aspiration. J Clin Endocrinol Metab. 2014; 99(2):510-6.

90. Kim SY, Han KH, Moon HJ, Kwak JY, Chung WY, Kim EK. Thyroid nodules with benign findings at cytologic examination: results of long-term followup with US. Radiology. 2014;271(1):272-81.

91. Ashcraft MW, Van Herle AJ. Management of thyroid nodules. II: Scanning techniques, thyroid suppressive therapy, and fine needle aspiration. Head Neck Surg. 1981;3(4):297-322.

92. Yoon JH, Kwak JY, Moon HJ, Kim MJ, Kim EK. The diagnostic accuracy of ultrasound-guided fine-needle aspiration biopsy and the sonographic differences between benign and malignant thyroid nodules $3 \mathrm{~cm}$ or larger. Thyroid. 2011:21(9):993-1000.

93. Kwak JY, Koo H, Youk JH, et al. Value of US correlation of a thyroid nodule with initially benign cytologic results. Radiology. 2010;254(1):292-300.

94. Rosario PW, Purisch S. Ultrasonographic characteristics as a criterion for repeat cytology in benign thyroid nodules. Arq Bras Endocrinol Metabol. 2010;54(1):52-5

95. Durante C, Costante G, Lucisano G, et al. The natural history of benign thyroid nodules. Jama. 2015;313(9):926-35.

96. Burch HB, Burman KD, Cooper DS, Hennessey JV, Vietor NO. A 2015 Survey of Clinical Practice Patterns in the Management of Thyroid Nodules. J Clin Endocrinol Metab. 2016;101(7):2853-62. jc20161155.

97. Varshney R, Forest VI, Mascarella MA, et al. The Mcgill thyroid nodule score does it help with indeterminate thyroid nodules? J Otolaryngol Head Neck Surg. 2015:44:2.

98. Shi $Y$, Ding $X$, Klein $M$, et al. Thyroid fine-needle aspiration with atypia of undetermined significance: a necessary or optional category? Cancer. 2009: 117(5):298-304.

99. Davidov T, Trooskin SZ, Shanker BA, et al. Routine second-opinion cytopathology review of thyroid fine needle aspiration biopsies reduces diagnostic thyroidectomy. Surgery. 2010;148(6):1294-9. discussion 9-301.

100. Cibas ES, Baloch ZW, Fellegara G, et al. A prospective assessment defining the limitations of thyroid nodule pathologic evaluation. Ann Intern Med. 2013;159(5):325-32.

101. Baloch Z, LiVolsi VA, Jain $P$, et al. Role of repeat fine-needle aspiration biopsy (FNAB) in the management of thyroid nodules. Diagn Cytopathol. 2003;29(4):203-6.

102. Yang J, Schnadig V, Logrono R, Wasserman PG. Fine-needle aspiration of thyroid nodules: a study of 4703 patients with histologic and clinical correlations. Cancer. 2007:111(5):306-15.

103. Nikiforov YE, Carty SE, Chiosea SI, et al. Highly accurate diagnosis of cancer in thyroid nodules with follicular neoplasm/suspicious for a follicular neoplasm cytology by ThyroSeq 22 next-generation sequencing assay. Cancer. 2014;120(23):3627-34.

104. Moon HJ, Kwak JY, Kim EK, et al. The role of BRAFV600E mutation and ultrasonography for the surgical management of a thyroid nodule suspicious for papillary thyroid carcinoma on cytology. Ann Surg Oncol. 2009:16(11):3125-31.

105. Gharib H, Papini E, Paschke R, et al. American Association of Clinical Endocrinologists, Associazione Medici Endocrinologi, and EuropeanThyroid Association Medical Guidelines for Clinical Practice for the Diagnosis and Management of Thyroid Nodules. Endocr Pract. 2010;16 Suppl 1:1-43.

106. Cobin $\mathrm{RH}$, Gharib H, Bergman DA, et al. AACE/AAES medical/surgical guidelines for clinical practice: management of thyroid carcinoma. American Association of Clinical Endocrinologists. American College of Endocrinology. Endocr Pract. 2001;7(3):202-20.

107. Orija IB, Pineyro M, Biscotti C, Reddy SS, Hamrahian AH. Value of repeating a nondiagnostic thyroid fine-needle aspiration biopsy. Endocr Pract. 2007; 13(7):735-42.

108. Suh $\mathrm{CH}$, Baek JH, Kim KW, et al. The Role of Core-Needle Biopsy for Thyroid Nodules with Initially Nondiagnostic Fine-Needle Aspiration Results: A Systematic Review and Meta-Analysis. Endocr Pract. 2016; 22(6):679-88.

109. Moon HJ, Kwak JY, Choi YS, Kim EK. How to manage thyroid nodules with two consecutive non-diagnostic results on ultrasonography-guided fineneedle aspiration. World J Surg. 2012;36(3):586-92. 
110. Moosa M, Mazzaferri EL. Outcome of differentiated thyroid cancer diagnosed in pregnant women. J Clin Endocrinol Metab. 1997;82(9):2862-6.

111. Uruno T, Shibuya H, Kitagawa W, Nagahama M, Sugino K, Ito K. Optimal timing of surgery for differentiated thyroid cancer in pregnant women. World J Surg. 2014;38(3):704-8.

112. Messuti I, Corvisieri S, Bardesono F, et al. Impact of pregnancy on prognosis of differentiated thyroid cancer: clinical and molecular features. Eur J Endocrinol. 2014;170(5):659-66.

113. Schneider AB, Ron E, Lubin J, Stovall M, Gierlowski TC. Dose-response relationships for radiation-induced thyroid cancer and thyroid nodules: evidence for the prolonged effects of radiation on the thyroid. J Clin Endocrinol Metab. 1993;77(2):362-9.

114. Curtis RE, Rowlings PA, Deeg HJ, et al. Solid cancers after bone marrow transplantation. N Engl J Med. 1997;336(13):897-904.

115. Pacini F, Vorontsova T, Demidchik EP, et al. Post-Chernobyl thyroid carcinoma in Belarus children and adolescents: comparison with naturally occurring thyroid carcinoma in Italy and France. J Clin Endocrinol Metab. 1997;82(11):3563-9.

116. Shibata Y, Yamashita S, Masyakin VB, Panasyuk GD, Nagataki S. 15 years after Chernobyl: new evidence of thyroid cancer. Lancet. 2001;358(9297):1965-6.

117. Hemminki K, Eng C, Chen B. Familial risks for nonmedullary thyroid cancer. J Clin Endocrinol Metab. 2005:90(10):5747-53.

118. McCartney CR, Stukenborg GJ. Decision analysis of discordant thyroid nodule biopsy quideline criteria. J Clin Endocrinol Metab. 2008;93(8):3037-44.

119. Cooper DS, Doherty GM, Haugen BR, et al. Revised American Thyroid Association management guidelines for patients with thyroid nodules and differentiated thyroid cancer. Thyroid. 2009;19(11):1167-214.

120. Moon WJ, Baek JH, Jung SL, et al. Ultrasonography and the ultrasoundbased management of thyroid nodules: consensus statement and recommendations. Korean J Radiol. 2011;12(1):1-14.

\section{Submit your next manuscript to BioMed Central and we will help you at every step:}

- We accept pre-submission inquiries

- Our selector tool helps you to find the most relevant journal

- We provide round the clock customer support

- Convenient online submission

- Thorough peer review

- Inclusion in PubMed and all major indexing services

- Maximum visibility for your research

Submit your manuscript at www.biomedcentral.com/submit

C) Biomed Central 